Indian Sorvice of Engineers, chief engineer and joint secretary to the Government of the United Provinces in the Public Works Department, Irrigation Branch, United Provinces; Mr. T. B. Tate, Indian Service of Engineers, chiof engineer and secretary to the Government of the Punjab in the Public Works Department, Irrigation Branch, Punjab. C.M.G.: Mr. R. Marrs, principal, Ceylon University College. C.I.E.: Mr. C. E. L. Gilbert, Indian Forest Service, chief conservator of forests, Bombay Presidency, Bombay; Dr. D. Penman, chief inspector of mines in India, and lately principal, Indian School of Mines, Dhanbad; Rao Bahadur Tiruvadi Sambasivaiyer Venkataraman, Indian Agricultural Service, sugarcane expert, Imperial Cane Breeding Station, Coimbatore; Mr. H. L. O. Carrett, Indian Educational Service (retired), lately principal, Government College, Lahore, Punjab; Dr. G. C. Ramsay, deputy director of the Ross Institute of Tropical Hygiene, London School of Hygiene and Tropical Medicine. C.B.E.: Mr. C. Gillman, chief engineer, Railways, Tanganyika Territory; Mr. A. E. Hamp, chief engineer, Kenya and Uganda Railways and Harbours; Mr. G. Jeffrey, member of the Agricultural Bureau, State of South Australia; Mr. D. Mackay, for services in connexion with scientific exploration and survey in the interior of Australia; Mr. H. A. Lewis-Dale, deputy director of Works and Buildings, Air Ministry; Mr. A. G. H. White, lately librarian to the Royal Society.

O.B.E.: Rai Bahadur Mathura Prasad Bhola, lately deputy conservator of forests, United Provinces; Mr. C. Chaffer, principal technical officer, Compass Department, Admiralty; Mr. R. B. Crusher, assistant director of surveys, Palestine; Prof. S. M. Dixon, lately member of the Safety in Mines Research Board; Mr. P. E. L. Gethin, chief surveyor and director of civil aviation, Tanganyika Territory ; Mr. B. Hart, honorary consulting radiologist to the Doncaster Royal Infirmary; $\mathrm{Mr}$. E. W. D. Jackson, Indian Service of Engineers, executive engineer (irrigation), Meiktila Division, Burma; Mr. H. S. Kingsford, assistant secretary, Society of Antiquaries of London; Mr. R. H. Locke, superintendent, Horticultural Operations, New Delhi ; Dr. G. H. Pethybridge, lately mycologist and assistant director, Plant Pathological Department, Harpenden ; Mr. E. A. Smith, chief technical officer for fuel, H.M. Office of Works and Public Buildings; Mr. J. G. Strickland, assistant director of surveys, Uganda Protectorate. M.B.E. : Surendra Nath Chakravarti, Indian Service of Engineers, municipal engineer, Delhi; Mr. R. McKintosh, Indian Service of Engineers, executive engineer, Public Works Department, Madras; Mr. C. MacQuarie, agricultural surveyor, Medical Department, Tanganyika Territory; Mr. W. E. Pereira, Bombay Forest Service, personal assistant to the chief conservator of forests, Bombay Presidency, Bombay; Major H. C. Phillips, Indian Medical Department, superintendent of the Punjab Vaccine Institute, Lahore, Punjab; Mr. J. H. Smith, principal, Oaklands Farm Institute, and agricultural organizer for Hertfordshire.

\section{History and Significance of the Electron}

DR. KarL T. Compton, while professor of physics in Princeton University, performed and inspired a great deal of work on the phenomena of the electric discharge in gases, on the emission of electrons from surfaces and on ionization by electron impact. $\mathrm{He}$ is now president of the Massachusetts Institute of Technology. His article on "The Electron: its Intcllectual and Social Significance" published as a supplement in this issue (p. 229) contains a survey, written in general terms, of the development of our knowledge of the electron since its discovery at the end of last century. The discovery of the electron, and the application of the electron ideas, first to gas discharges, then to radioactivity, spectroscopy and atomic structure, opened a most rapid advance in physical science, leading up to contemporary views of atomic structure and of chemistry. Applied to technical sciences, particularly in the communication industries, the electron has assumed great commercial and social significance.

\section{Prof. C. N. Hinshelwood, F.R.S.}

Mr. C. N. Hinshelwood, who succeds Prof. Frederick Soddy as Dr. Lee's professor of inorganic and physical chemistry at Oxford, is a leader of physical chemistry in Great Britain. Still in his thirties, he has made a great reputation by his work on gas reactions. $\mathrm{He}$ was formerly fellow of Balliol College and University lecturer in chemical dynamics. $\mathrm{He}$ is a fellow of Trinity College, a fellow of the Royal Society, an honorary doctor of science of Dublin and a delegate of the Clarendon Press. $\mathrm{He}$ is the head of the Balliol and Trinity Colleges Laboratories, and is the first member of this school of physical chemistry to become professor at Oxford. $\mathrm{He}$ is a man of wide interests outside his professional work and, in particular, an expert linguist. At Oxford, professorships are attached to particular colleges. In the ordinary way Prof. Hinshelwood should migrate to, and become a fellow of, Exeter College on his appoint. ment. It has happily been arranged, however, that he remain at Trinity College, and in charge of the laboratories there, until an official University institute of physical chemistry be built in the Parks.

\section{Science in the U.S.S.R.}

REFerences were made in NAture of January 23 (p. 142), and January 30 (p. 185) to the position with regard to the International Congress of Genetics which was to have been held in Moscow this summer. A request for turther information was sent to His Excellency the Russian Ambassador, who has favoured us with a statement on the recent meetings of the Lenin Agricultural Academy (see NATURE, Jan. 30) and on the International Congress of Genetics. Dealing with the latter, the statement is as follows :

"As to the postponernent of the Genetics Congress, it is a fact that this was due to requests received by the organisers of the Congress from a number of 